\title{
中性子回折の材料工学への活用
}

鈴木徹也*

\section{Application of Neutron Diffraction to Materials Engineering}

\author{
Tetsuya Suzuki
}

\section{Synopsis}

Neutron diffraction is a one of powerful technique to measure the residual stress of crystalline materials. This technique is useful in industrial fields such as quality certification and engineering design of products. However, it is not well known how to use or how to utilize this technique. This article was written to introduce the neutron diffraction and it's application to materials engineering focused on residual stress measurement.

\section{1.はじめに}

「中性子回折」とはあまり聞きなれない言葉とお感じに なる方も多いだろう. 結晶性材料の内部情報を得る有効な 手段の一つであるにもかかわらず, 実験が行える施設が限 られること,また測定装置の操作, 解析にも技術を要する ため敬遠される場合もあるようだ.しかし最近では関係施 設の方々の努力により，勉強会が行われたり，中性子利用 のワークショップ,研究会なども頻繁に開催されるように なってきた。

材料の信頼性, 機能の向上を考える上で残留応力など材 料内部の情報を得ることは重要である.その手段の一つと して，ここでは中性子回折の概略を X 線回折，放射光な どとの比較の上で主にその侵入深さに注目して述べてい きたい.Table 1 にさまざまな材料に対して強度が $37 \%$ に 減衰する深さを示す ${ }^{1)}$. 従来物質の構造や結晶性材料の応
力評価には X 線回折が広く用いられてきた。現場では例 えば鉄鋼材料の熱処理や表面処理が原因で引き起こされ る残留応力の測定法として利用されている.鉄鋼材料では 通常の $\mathrm{X}$ 線の測定可能な侵入深さは数 $\mu \mathrm{m}$ である。 その ため, それ以上の深さの応力分布を知るためには電解研磨 などによって順次表面を除去し, 測定を繰り返す必要があ る.

一方, 放射光では高輝度, 高指向性で任意波長の高工ネ ルギ X 線が得られる．X 線の侵入深さはエネルギに依存 して変化し，Table 1 に示されるとおりエネルギが高いほ ど侵入深さが大きい。また, 空間分解能が高く, $1 \mu \mathrm{m}$ 以

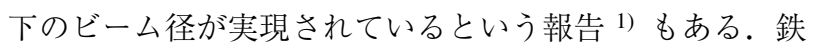
鋼材料であれば $1 \mathrm{~mm}$ までの測定深さにおいて高精度の測 定に大きな可能性がある. 放射光の測定ができる施設は世 界に 3 箇所あり, フランスの ESRF (European Synchrotron Radiation, 6GeV), 米国の APS (Advanced Photon Source,

Table1. Penetration depth of X-ray and thermal neutron ${ }^{1)}$.

\begin{tabular}{lccccc}
\hline Material & $\mathrm{Al}$ & $\mathrm{Ti}$ & $\mathrm{Fe}$ & $\mathrm{Ni}$ & $\mathrm{Cu}$ \\
\hline Thermal Neutron & 1230 & 50 & 85 & 40 & 53 \\
Synchrotron(150 keV) & 27 & 13 & 6.5 & 5 & 5 \\
Synchrotron(70 keV) & 15.4 & 3.8 & 1.4 & 1.0 & 1.3 \\
Synchrotron(40 keV) & 6.5 & 1.0 & 0.35 & 0.24 & 0.23 \\
Cu-K $\propto$ & 0.074 & 0.011 & 0.004 & 0.023 & 0.022 \\
\hline
\end{tabular}

2005 年 10 月 10 日受付

*茨城大学工学部超塑性工学研究センター, 工博 (Dr., Eng., The Research Center for Superplasticity, Faculty of Engineering, Ibaraki University) 
7GeV), そして日本の SPring-8 (7GeV) である.

中性子は電荷をもたないので, 数 $\mathrm{mm}$ から数 $\mathrm{cm}$ の範囲 の侵入深さを持ち, 通常の構造材料サイズの内部応力測定 では群を抜く性能を有する。また一般に X 線は原子核を とりまく電子の数に散乱強度が関係するので軽元素 (水素 など）を観測することが困難であるが，中性子の場合，散 乱が核散乱であるために, 元素の重さには無関係に散乱さ れ，重い元素も軽い元素も同程度に測定可能である．また 中性子はスピンをもっていることから磁性物質の内部磁 場によっても散乱される性質がある. 現在国内で中性子を 利用できる施設としては, 茨城県那珂郡東海村に日本原子 力研究所 (以後原研) の研究用原子炉 JRR-3 (Japan Research Reactor No.3) があり, 茨城県つくば市の高エネルギー加速 器研究機構（以後 KEK）には加速器を用いたパルス中性 子源 KENS がある.なお後述するが KENS の装置は 2005 年 度中には停止し，2007 年度から東海村に建設中の J-PARC (Japan Proton Accelerator Research Complex) に移行する.

\section{2. 角度分散法と飛行時間法}

中性子回折を用いた測定法には大きく 2 種類がある. JRR-3 に設置されている装置は，単色化した中性子を用い る角度分散型回折装置である。一方 KENS や J-PARC のパ ルス中性子源を利用した装置は, 白色中性子を用いた波長 分散型（エネルギー分散型）回折装置である.すなわち検 出器の位置は固定され, Bragg 反射を起こす波長を観測す る.この場合飛行時間 (TOF: Time of Flight) 法と呼ばれる 測定が行われている.ここでは角度分散法と飛行時間法に ついてその概略を解説する。

\section{1 角度分散法}

モノクロメーター結晶を利用することで, 原子炉におい て連続的に発生する白色の熱中性子から，単一波長 (単一 エネルギー)のみの中性子を抽出することができる。この 単一波長中性子を測定試料に照射した後回折される中性 子の個数と回折角を検出器により観測する方法を角度分 散法と呼ぶ。すなわち，ある回折面 hkl の格子面間隔を $\mathrm{d}_{\mathrm{hkl}}$, 入射中性子の波長を $\lambda$ とすれば, Braggの条件式よ り $2 \mathrm{~d}_{\mathrm{hkl}} \sin \theta=\mathrm{n} \lambda$ となる $2 \theta$ を測定する. Fig. 1 に角度 分散法により測定したピークプロファイルの例を示す ${ }^{2)}$. 一般に測定は $2 \theta$ で $0.1^{\circ}$ 間隔で行われ，Fig.1では $3^{\circ}$ 範 囲の測定で 31 点の測定となる，ピークの中心位置はおお むね左右対称であることから Gaussian フィッティングに より決定される。試験片のサイズはかなり自由であるが, ここでは $\phi 5.5 \mathrm{~mm} \times 10 \mathrm{~mm}$ の丸棒を用いた. 通常この州

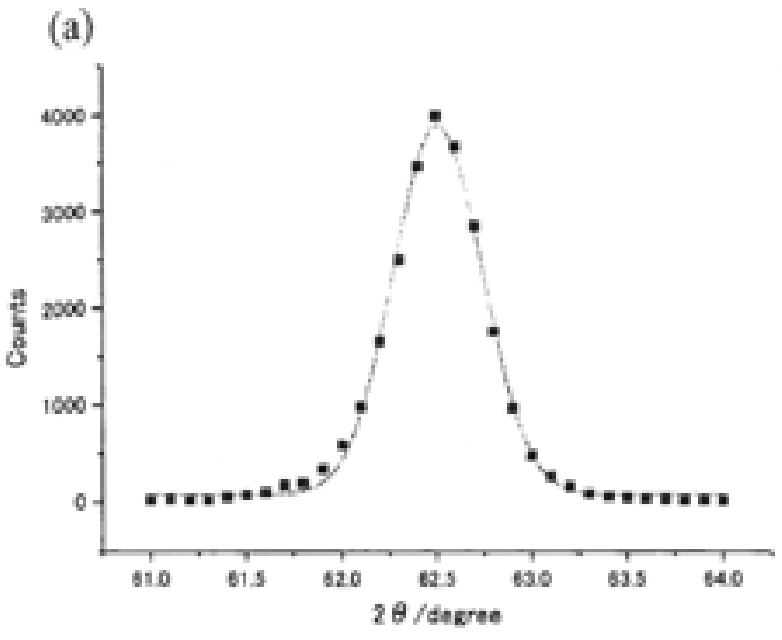

(b)

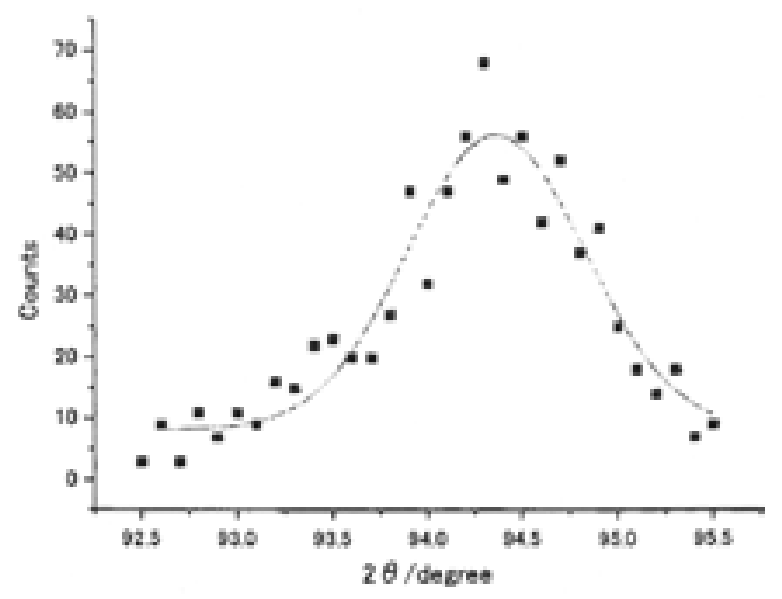

Fig.1. Example diffraction profiles and Gaussian fitting for specimen P2 for (a) (110) at $0^{\circ}$ and (b) (200) at $22.5^{\circ}$.

イズであれば回折面によっても異なるが 1 ピークの測定 時間は $1 \sim 3 \mathrm{ks}$ 程度である.ただし多相材で体積率の低 い相の測定, 強い集合組織がある場合はこの限りではな い. Fig.1 (a) および (b) にはその極端な例を示した. 試料 は伸線加工したパーライト鋼で (a) は伸線方向に平行な面 のフェライト (110) ピーク, (b) は (a) の測定方向から $22.5^{\circ}$ 傾けた方向におけるフェライト (200) ピークのプロファイ

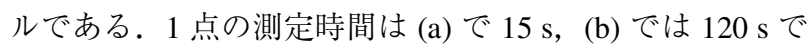
ある.伸線加工したパーライト鋼のフェライト相には変形 集合組織の影響で伸線方向に強い〈110〉繊維集合組織が 形成されている，そのため，(a) に示すような伸線方向の (110) ピークは非常に強く測定されるが，(b)のように測定 時間が 4 倍であっても極めて弱い場合もある.ピークの形 状およびCount 数から, その差は明瞭である。このように 測定条件, 精度は試料の素性に大きく左右されることに注 意する必要がある。 


\section{2 飛行時間法}

Fig.2 に飛行時間法の模式図を示す。加速器を利用した パルス中性子源では, 加速器からの陽子が中性子発生用 ターゲットにぶつかった瞬間にパルス状に中性子が発生 する。この発生からそれぞれの中性子はエネルギーの違い に従って異なるタイミングで試料にぶつかってくる.散乱 された中性子は検出器によって検出されるが, 中性子源一 試料-検出器までの中性子の飛行時間 $\mathrm{t}$ が異なることから, それぞれの時刻に観測された中性子のエネルギーを知る ことができる。これを飛行時間 (TOF: Time of Flight) 法と いう，中性子の速度を $\mathrm{v}$, 中性子発生後，試料を経て検出 器に至る距離を $\mathrm{L}$ とすると, 中性子の速度は $\mathrm{v}=\mathrm{L} / \mathrm{t}$ によ り決定できる。この式をド・ブロイの関係 $\lambda=\mathrm{h} / \mathrm{mv} （ \lambda$ : 中性子の波長, $\mathrm{h}$ : プランクの定数, $\mathrm{m}$ ：中性子の質量）に 代入すると $\lambda=\mathrm{ht} / \mathrm{mL}$ となり $\mathrm{t}$ から $\lambda$ が求まり, さらに Bragg の条件から格子面間隔 $\mathrm{d}_{\mathrm{hkl}}$ が計算できる ${ }^{3)}$. Fig.3に 飛行時間法による測定例を示す ${ }^{4)}$. 試料はパーライト鋼で 測定時間は $7.2 \mathrm{ks}$ である.すべての回折プロファイルが同 時に得られ，また面間隔の小さいものまで明瞭に測定でき る特徵がある。またプロファイルを拡大するとパーライト 中のセメンタイトのピークも見られることがわかる.飛行 時間法により得られるプロファイルは左右非対象である ためプロファイル解析にはFig.4 に示すような工夫が必要
となる.ピークトップより $\mathrm{d}$ のさい側では Pseudo- Voight function (Gauss 関数と Lorentz 関数の convolution), ピー

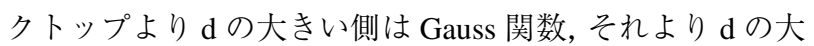

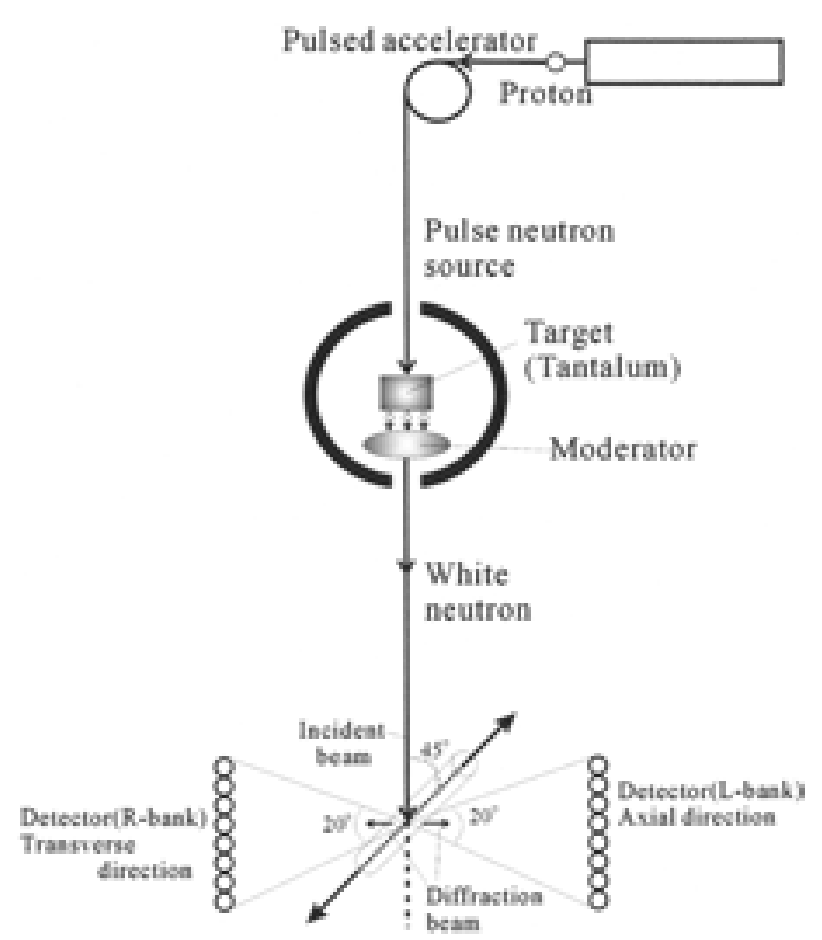

Fig.2. Layout of tensile specimen apparatus and neutron diffractmeter of TOF method.

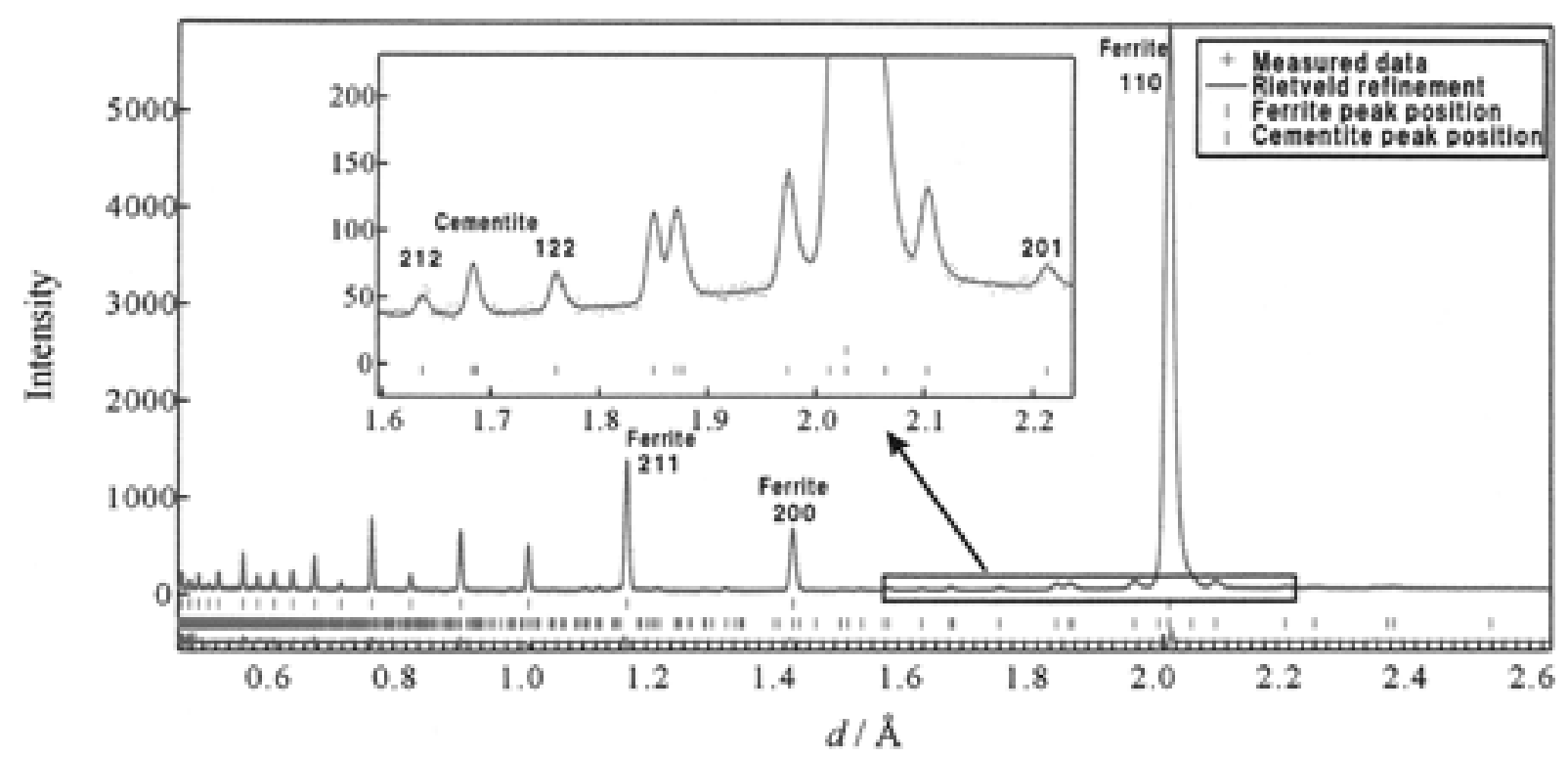

Fig.3. Diffraction patterns of pearlitic steels obtained by the TOF method:overall view of the profile. 


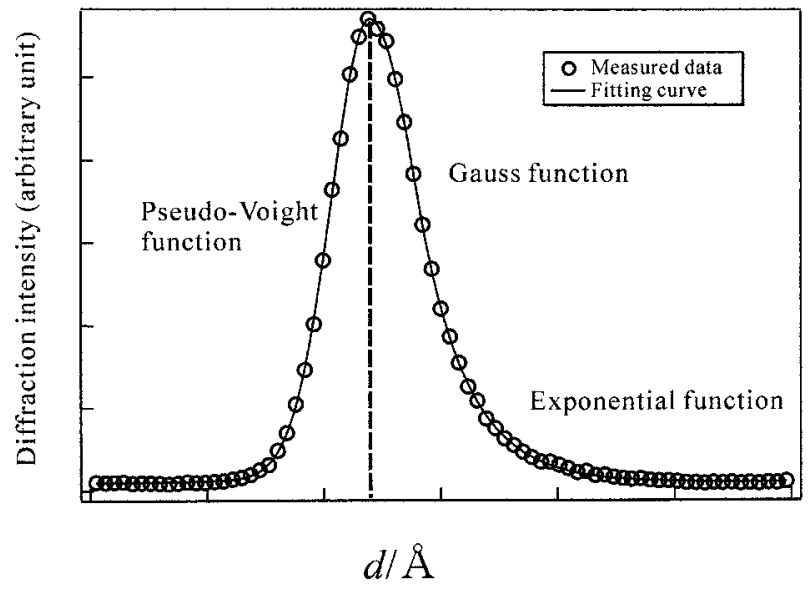

Fig.4. Profile function used for the single peak fitting analysis of TOF method.

きい側で Exponential 関数でフィッティングすると単一 ピークのフィッティング精度が良いことがわかっている5). またこれとは別に X 線解析と同様の手法により全ピーク のプロファイル解析も行われている. TOF 中性子回折パ ターンは多様な情報を含んでいる. 数值データだけとりあ げても, ピーク位置から格子定数, 積分強度 (回折プロファ イルの面積) から結晶構造パラメーター（分率座標, 占有 率, 原子変位パラメーター), プロファイルの広がりから 格子定数の歪みと結晶子サイズ, 混合物中の各相の尺度因 子から質量分率が得られる.さらに粉末中性子回折では積 分強度から各磁性原子サイトの磁気モーメントまで決定 できる.物質科学において基本的に重要なこれらの物理量 を同時に求め得る汎用粉末回折デー夕解析技術がリート ベルト法6)である。リートベルト法では，X線・中性子回 折パターン全体を対象として構造パラメーターと格子定 数を直接精密化する. 国内の Rietveld 解析プログラムに は, RIETAN ${ }^{7)}$ がある。

\section{3. 中性子による応力解析}

測定した回折面 $\mathrm{hkl}$ の格子面間隔を $\mathrm{d}_{\mathrm{hkl}}$ として, 無応力 状態の $\mathrm{hkl}$ 回折の格子面間隔を $\mathrm{d}_{\mathrm{hkl}}^{0}$ としたとき, 各回折面 の格子ひずみ $\varepsilon_{\mathrm{hkl}}$ は

$$
\varepsilon_{\mathrm{hkl}}=\left(\mathrm{d}_{\mathrm{hkl}}-\mathrm{d}_{\mathrm{hkl}}^{0}\right) / \mathrm{d}_{\mathrm{hkl}}^{0} \cdots
$$

で与えられる。なお，無応力状態の格子面間隔である $\mathrm{d}_{\mathrm{hkl}}^{0}$ は中性子応力測定の信頼性に大きく関係し, これを正確に 求める手法が模索されている。一般には測定試料の粉末状 試料を別途作製する方法あるいは焼きなまし試料の格子 面間隔を $\mathrm{d}_{\mathrm{hkl}}^{0}$ とする手法などがとられている.厳密には塑 性異方性などが原因で結晶粒間に相互に発生する第二種 応力などを考慮に入れる必要があるとされている ${ }^{8)}$.
直交する 3 つの座標軸に沿って応力 $\sigma_{11}, \sigma_{22}, \sigma_{33}$ が 働いている場合，それぞれの方向のひずみ $\varepsilon_{11}, \varepsilon_{22}, \varepsilon_{33}$ との関係は, 以下の式 (2)で表される.

$$
\begin{aligned}
& \sigma_{11}=\frac{E}{(1+v)}\left\{\varepsilon_{11}+\frac{v}{(1-2 v)}\left(\varepsilon_{11}+\varepsilon_{22}+\varepsilon_{33}\right)\right\} \\
& \sigma_{22}=\frac{E}{(1+v)}\left\{\varepsilon_{22}+\frac{v}{(1-2 v)}\left(\varepsilon_{11}+\varepsilon_{22}+\varepsilon_{33}\right)\right\} \\
& \sigma_{33}=\frac{E}{(1+v)}\left\{\varepsilon_{33}+\frac{v}{(1-2 v)}\left(\varepsilon_{11}+\varepsilon_{22}+\varepsilon_{33}\right)\right\}
\end{aligned}
$$

ここで E はヤング率, $\mathrm{v}$ はポアソン比を示す. 中性子回折 で 3 方向から $\mathrm{d}_{\mathrm{hkl}}$ を測定し, 式(1)により， $\varepsilon_{11}, \varepsilon_{22}, \varepsilon_{33}$ を求めた後に式 (2) により応力状態を求めることができ る。なお，弾性定数には回折面依存性があるため，Eおよ び $\mathrm{v}$ には測定回折面固有の $\mathrm{E}_{\mathrm{hkl}}$ および $\mathrm{v}_{\mathrm{hkl}}$ を用いればより 精密な計算ができる.

\section{4. 中性子回折による残留ひずみ 測定例}

著者らの研究グループではこれまで中性子回折を利用 して鉄鋼材料のさまざまな研究を行ってきたが,ここでは その一例 2)を紹介したい. 伸線加工されたパーライトは 負荷方向により強度異方性を有することが知られている. 伸線加工した場合ラメラ組織は伸線方向に平行に配向し, また主に構成相のフェライトの变形集合組織が形成され る.また後述するが硬いセメンタイトとやわらかいフェラ イトで塑性変形挙動が異なるために相応力が発生する.こ れらさまざまな要因が考えられる中, 中性子回折を用いて 伸線パーライト鋼の強度異方性の原因について検討した. 供試材は $0.853 \mathrm{C}-0.26 \mathrm{Si}-0.82 \mathrm{Mn}-0.011 \mathrm{P}-0.0061 \mathrm{~S}$ $0.0049 \mathrm{~N}-0.020 \mathrm{Al}-0.045 \mathrm{Cr}-0.0007 \mathrm{O}$ の過共析鋼で $\phi 11$ $\mathrm{mm}$ である。この試料をパテンティング処理によりフル パーライトとしたもの (P1), および断面減少率で $75 \%$ 伸 線加工し, $\phi 5.5 \mathrm{~mm}$ としたもの $(\mathrm{P} 2)$, これを $423 \mathrm{~K}$ で 12.6 $\mathrm{ks}$ 時効処理したもの (P3), $698 \mathrm{~K}$ で $0.6 \mathrm{ks}$ のひずみ除去焼 鈍をしたもの (P4), そして球状化組織を得るために $963 \mathrm{~K}$ で $18 \mathrm{ks}$ 焼鈍処理をしたもの (P5) を準備した. 中性子測定 に先立って組織観察および伸線方向に引張試験, 伸線方向 に対して方向を変化させて圧縮試験を行った. 組織観察の 結果, P1, P5 以外は伸線方向にラメラが平行に配向した組 織となっていることがわかった.試験の概略図を Fig.5に， 試験結果を Table 2 に示す. 伸線加工後の P2 および P3 に おいて圧縮と引張で降伏強度に差があり, また圧縮する角 度によっても強度が異なる強度異方性を示した.この試料 
Table 2. Measured tensile and compressive yield stresses of the different samples (GPa).

\begin{tabular}{c|c|c|c|c}
\hline \multirow{2}{*}{ Specimen } & \multirow{2}{*}{ Tension } & \multicolumn{3}{|c}{ Cmpression } \\
\cline { 3 - 5 } & & $\psi=0^{\circ}$ & $\psi=45^{\circ}$ & $\psi=90^{\circ}$ \\
\hline P1 & 1.00 & 1.05 & 0.98 & 1.05 \\
P2 & 2.05 & 1.45 & 1.53 & 1.58 \\
P3 & 2.15 & 1.55 & 1.72 & 1.77 \\
P4 & 1.60 & 1.60 & 1.67 & 1.52 \\
P5 & 0.70 & 0.57 & 0.60 & 0.58 \\
\hline
\end{tabular}

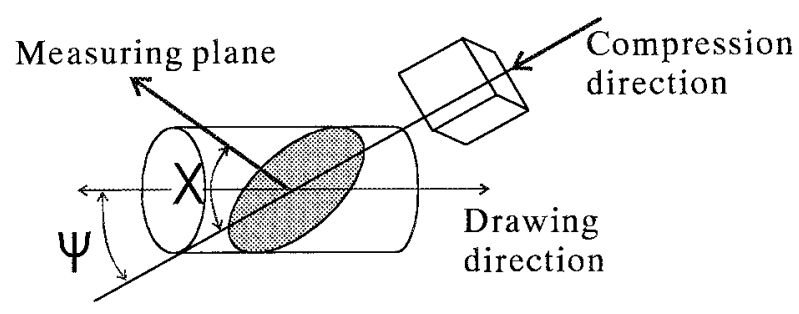

Fig.5. Schematic showing geometrical parameters in the compression, residual strain measurements.

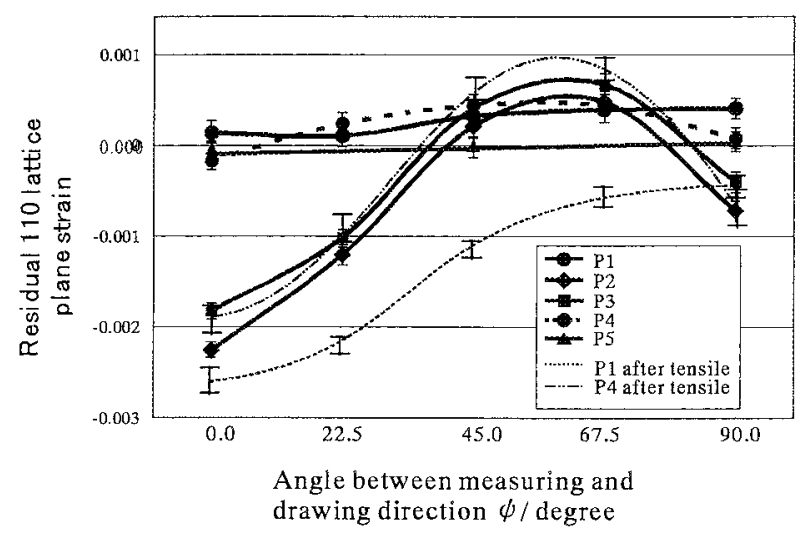

Fig.6. Residual (110) lattice plane strains of specimens P1 to P5 as a function of measuring angle.

に対して Fig.5 に示すように測定方向を変えて角度分散法 により中性子回折試験を行った結果を Fig.6 に示す。中性 子の測定は原研のJRR-3に設置されている残留応力測定装 置 RESA を用いた.P1, P4 およびP5 についてはどの方向 においてもフェライト相の残留ひずみは観測されず, 残留 応力が非常に小さいことがわかる。一方, 強度に異方性が 見られた P2, P3 においてフェライト相に残留応力が認め られ，またその残留応力も方位によって異方性を有するこ とがわかった。この結果からセメンタイト相とフェライト 相の間に塑性変形によって相応力が導入されたことがわ かる.さらにこの研究では別に測定した集合組織の結果も あわせて検討し, 伸線パーライト鋼の強度異方性の主因が 残留応力にあることを明らかにした. Fig.7 は P2 試験片に おいてフェライト hklごとに残留ひずみをまとめたもので

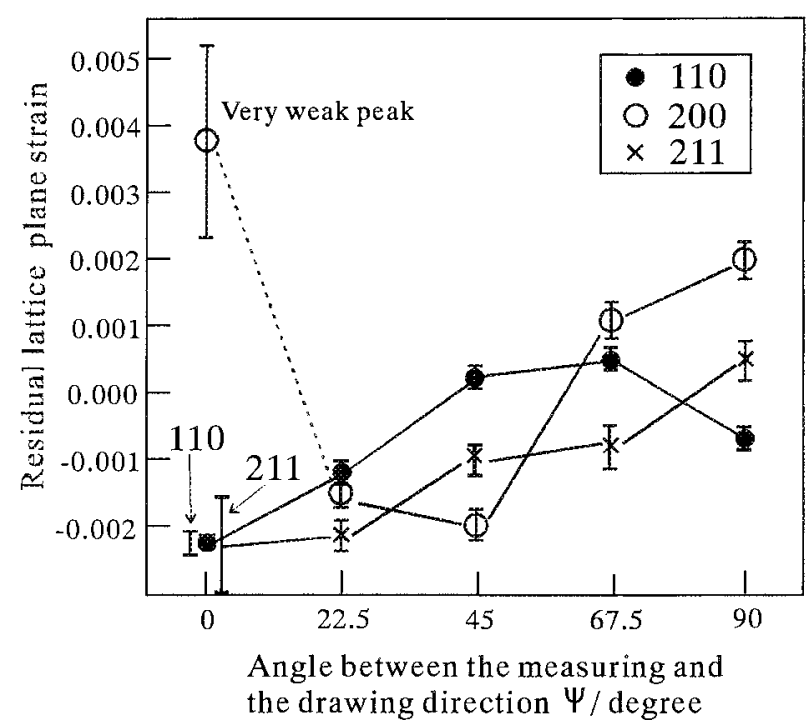

Fig.7. Residual strain as a function of measuring angle for different lattice planes in specimen P2.

ある.各hklで方向により異なる残留ひずみを示している. このことからパーライト中ではフェライトとセメンタイ トの相応力のみならず, フェライトブロック間の塑性異方 性に起因したブロック応力も存在することが容易に推測 できる.このパーライトの階層的不均一変形挙動を追うた めに最近では KEK の高分解能中性子回折装置内に引張試 験機を導入し, 飛行時間法によって引張試験中のその場中 性子回折を行い成果を上げつつある ${ }^{9)}$.この他にもパーラ イト鋼に関する研究 ${ }^{10)}$, 伸線フェライト鋼に関する研究 ${ }^{11)}$, 温度を変化させて変態に伴う挙動の変化, 加工熱処理中の その場中性子回折, 溶接材 ${ }^{8)}$, 高周波焼入棒鋼の残留応力 分布に関する研究 ${ }^{12)}$ などが行われているが紙面の都合上 ここでは割愛させていただきたい.

\section{J-PARC について}

現在, 原研と KEK の共同事業して大強度陽子加速器計 画が進められており, $1 \mathrm{MW}$ クスのパルス中性子源施設 が建設予定である。東海村の敷地に 2001 年に建設が開始 され 2007 年度の完成を予定している.J-PARC は $400 \mathrm{MeV}$ 
陽子線形加速器, $3 \mathrm{GeV}$ シンクロトロン, $50 \mathrm{GeV}$ シンク ロトロン, 物質生命科学実験施設, 原子核実験施設, ニュー トリノ実験施設および核変換実験施設より成り立ってい る ${ }^{13)}$. 施設内にエネルギー分散型の応力測定用中性子回 折装置の設置が計画されており，現状では困難である 1 $\mathrm{mm}^{3}$ ゲージ体積内の短時間応力測定，また， $0.2 \%$ 以下の 装置分解能 (鉄鋼材料で士 $20 \mathrm{MPa}$ 程度) を目指している. また大型試料台の設置も準備されている.さまざまな物質 の原子構造とその機能に関する測定精度, 迅速性が現在の およそ 100 倍程度にもなると予定されている.海外を含め 多くの研究者が活用できるように運用, 実験支援, デー夕 解析支援など検討が進められている。

\section{6. おわりに}

以上，非常に雑駁ではあったが中性子回折の原理，測定 例など一部紹介させていただいた。冒頭でも述べたが中性 子回折も万能ではなく, 特にその測定対象の深度, 求める 精度などにより X 線，放射光などと使い分けることが必 要と思われる.使い始めるまで少し敷居が高く（最近では ずいぶん軽減されているが)，またマシンタイムも限られ ているため, 有効なデー夕を安定して得るためにはノウハ ウが必要となる。しかし，関係者の努力により測定が始 まってしまえば自動化されている部分も多く, 最近ではず いぶん徹夜実験も減ってきた。この稚拙な文章をお読みい ただき少しでも中性子回折に興味をもっていただければ と願っている。

\section{(文 献)}

1）田中啓介, 秋庭義明:材料, 52 (2003), 1435.

2) T. Suzuki, Y. Tomota, M. Isaka, A. Moriai, N. Minakawa and Y. Morii: ISIJ Int., 44(2004), 1426.

3) 神山崇:日本結晶学会誌, 46(2004), 259.

4）友田陽:熱処理, 43(2004), 73.

5）鳥居周輝, 友田陽, 鈴木徹也, 朴鍾皓, 及川健一, 神山崇： 日本機械学会論文集 (A編), 68(2002), 1540.

6) H.M.Rietveld:J.Appl.Crystallogr., 2(1969), 65.

7) T.Ohta, F.Izumi, K.Oikawa, T.Kamiyama:Physica B, 234236(1997), 1093.

8) 鈴木裕士:実験力学, 5(2005), 57.

9）諸岡聡, 鈴木徹也, 友田陽, 塩田佳徳, 神山崇: 鉄と鋼, 91 (2005), 816.

10）蟹江厚臣, 友田陽, 鈴木徹也, 鳥居周輝, 盛合敦, 皆川宣 明, 森井幸生, 神山崇:材料, 53(2004), 772.
11) Y. Tomota, T.Suzuki, A. Kanie, Y. Siota, M.Uno, A. Moriai, N. Minakawa and Y. Morii :Acta Materialia, 53(2005), 463.

12）徳田玄聖, 友田陽, 鈴木徹也, 川崎一博, 盛合敦, 皆川宣 明, 森井幸生: 鉄と鋼, 90 (2004), 1038.

13）新井正敏:実験力学, 5(2005), 3 . 